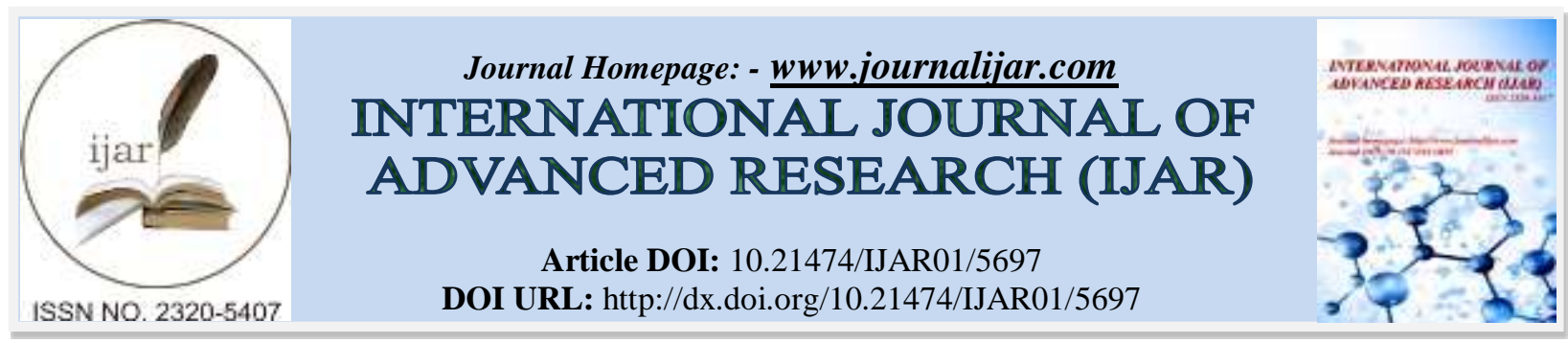

RESEARCH ARTICLE

\title{
GANODERMA LUCIDUM (FR.) P. KARST AMELIORATE MITOCHONDRIAL DYSFUNCTION IN DOXORUBICIN-INDUCED CARDIOTOXICITY IN RATS.
}

\author{
Ravindran. K. Veena and K. K. Janardhanan. \\ Department of Microbiology, Amala Cancer Research Centre, Amala Nagar , Thrissur - 680 555, Kerala, India.
}

\section{Manuscript Info}

Manuscript History

Received: 22 August 2017

Final Accepted: 24 September 2017

Published: October 2017

\section{Abstract}

Copy Right, IJAR, 2017,. All rights reserved.

\section{Introduction:-}

Doxorubicin (DOX) is an anthracycline antibiotic widely used in cancer chemotherapy. However, clinical usefulness of this antineoplastic agent is delimited by severe and cumulative cardiotoxicity. It is broadly accepted that myocardial oxidative stress and the accumulation of free radicals are involved in DOX induced cardiotoxicity (Hellmann et al ,1998). Mitochondria are known as the 'power house' of the cell. They are abundant in cardiomyocytes . More than $90 \%$ of the energy utilized by cardiomyocytes is produced by mitochondrial respiration which is tightly coupled to the tricarboxylic acid (TCA) cycle .

Mitochondria are considered as one of the major target in DOX chemotherapeutic regiments. DOX antineoplastic activity is occurred through DNA - Topoisomerases II $\alpha$ adduct formation (Khiati et al ;2014). DOX - $\beta$ adduct induced cardio toxicity arises in different ways; deleterious free radical generation by complexes with iron, redox cycling, mitochondrial dysfunction, DNA damage, alterations in protein and lipid, calcium overlord etc. Mitochondrial respiration is generally recognized as the prime source of reactive oxygen species (ROS). Increased mitochondrial oxidative stress results in mitochondrial proteins damage and lipid peroxidation. ROS generation mainly occur through Complex I and III. During normal mitochondrial respiration, about $1 \%$ of oxygen is converted in superoxide radical (O2.-) which is further converted into hydrogen peroxide $\left(\mathrm{H}_{2} \mathrm{O}_{2}\right)$ which is able to cross the membranes and react with free metal ions to form the hydroxyl radical (HO.). In general, free radicals generated within the mitochondria are neutralized by their own antioxidant defence system (Tsutsui et al ;2008). A chronic increase of mitochondrial free radical production in the heart alters this redox balance. Among the previously mentioned reasons, DOX-induced cardiotoxicity has a strong mitochondrial component . Mitochondria from DOX-treated animals show traces of the drug, which might be due to its binding affinity for particular biomolecules within the organelle. As with nuclear DNA, DOX also forms adducts with mitochondrial DNA (mtDNA) (Minotti et al ; 2004), cardiomyocyte TOP II $\alpha$ mechanism . Goormaghtigh et al (1990) reported that DOX form complexes with Cardiolipin, one of the most abundant phospholipid in the inner mitochondrial membrane. Accumulated DOX in the cardiomyocyte initiate direct and delitorious side effects include : a) stimulation of ROS production, b) induction of MTP(Mitochondrial Transition Permiability) and c) inhibition of OXPHOS (oxidative phosphorylation) etc .

Corresponding Author:- K. K. Janardhanan

Address:- Department of Microbiology, Amala Cancer Research Centre , Amala Nagar , Thrissur - 
Ganoderma lucidum (Fr.) P.Karst - is well known in vivid names such as Lingzhi, Reishi and Youngzhi in Asian countries and that has been used as a folk medicine to preserve human vitality and to promote longevity in traditional Chinese Medicine over 2000 years. Now it is popularly used as a nutriceutical in Western countries (Sliva et al ;2004). Both the fruiting body and mycelia of G. lucidum are reported to contains a variety of chemical components including triterpenes, polysaccharides, nucleosides, steroids, fatty acids , alkaloids , proteins, peptides, amino acids etc (Wasser , 2010). Among these polysaccharides and triterpenes are the major components. Previous investigations in our laboratory showed that G. lucidum occurring in south India possessed significant antioxidant, anti- inflammatory, anti tumor, anti- nociceptive, nephroprotective , anti- aging and radioprotective properties (Lakshmi et al ; 2003 ,Smina et al ; 2011 ). Sudheesh et al (2010) reported that fruiting bodies of G.lucidum ameliorated the dysfunctions in heart mitochondrial enzymes and respiratory chain complexes in aged rats. However, the effect of Ganoderma on the activities of Krebs cycle dehydrogenases or enzymes complexes of electron transport chain (ETC) has not reported in DOX induced toxicity.

\section{Materials and Methods:-}

Animals:-

Male Wistar rats weighing $220 \pm 20$ g were purchased from Small Animal Breeding Centre, Agricultural University, Mannuthy, Thrissur, Kerala, India. Animals were kept for a week under standard environmental conditions with free access to food (Sai Durga Feeds and Foods, Bangalore, India) and water ad libitum. Animal experiments were carried out following the guidelines of CPCEA (Government of India) and approval of the Institutional Animal Ethics Committee (IAEC) sanction No .149/1999/CPCSEA, Amala Cancer Research Centre , Amala Nagar , Thrissur, Kerala , India.

\section{Chemicals :-}

Doxorubicin hydrochloride (Doxowin), Wintac Pvt .Ltd. Bangalore, India was purchased from the local market. All other chemicals and reagents used in the experiments were of analytical grade.

\section{Preparation of Extracts of G. lucidum:-}

Sporocarps of G. lucidum growing on the living Caesalpinia coriaria Wild. trees in Thrissur District, Kerala, India were collected. The specimen was identified and the identification was confirmed by available literature.

The fruiting bodies were cut into small pieces and dried at $45-50^{\circ} \mathrm{C}$ for $48 \mathrm{hrs}$ and powered. One hundred gram samples of powered materials were defatted with petroleum ether using Soxhlet apparatus. The defatted material was again extracted with $70 \%$ aqueous ethanol for $12 \mathrm{hrs}$. It was filtered through Whatman No. 1 filter paper. The solvent was evaporated at $40^{\circ} \mathrm{C}$ using a rotary vacuum evaporator and finally lyophilized. The yield of the extract (GLF) was $3.42 \%$.

Effect of Ganoderma lucidum on the mitochondrial dehydrogenases and respiratory complexes in the heart of Doxorubicin induced Rats:-

The animals were divided into 5 groups of six animals each and treated as follows. Group I treated with distilled water was kept as normal. Group II treated with DOX (i. p) was kept as control. Group III and IV were administered with GLF at concentrations of 250 and $500 \mathrm{mg} / \mathrm{kg}$ respectively. Group V was administered with DL $-\alpha-\mathrm{Lipoic}$ acid; $100 \mathrm{mg} / \mathrm{kg}$ (dissolved in $0.5 \% \mathrm{NaOH})$ and taken as standard. The DOX was administrated once daily $(6 \mathrm{mg} / \mathrm{kg})$ i. $\mathrm{p} 0.75 \mathrm{ml}$ for 3 alternative days (cumulative dose of $18 \mathrm{mg} / \mathrm{kg}$ ) to group II, III, IV and V. The extracts were given once daily for five days prior to DOX injection to group III and IV and continued along with DOX injection for three more days .The animals were sacrificed $24 \mathrm{hr}$ after last dose of treatments. Heart was immediately excised, washed and kept at $-70^{0} \mathrm{C}$ for mitochondrial analyses.

\section{Preparation of mitochondrial fraction:-}

Heart tissue homogenate of rats (about 10\%) was prepared in 50 mmol/l phosphate buffer $\left(\mathrm{p}^{\mathrm{H}} 7.0\right.$ ) containing 0.25 $\mathrm{mol} / \mathrm{l}(\mathrm{w} / \mathrm{v})$ sucrose . Homogenate was centrifuged initially at $1,000 \mathrm{~g}$ for $10 \mathrm{~min}$ at $4^{0} \mathrm{C}$ and the supernatant was subjected to $16,000 \mathrm{~g}$ for 20 minutes at $4^{0} \mathrm{C}$ in a cooling centrifuge. The mitochondrial pellets were washed twice with phosphate buffer to remove the sucrose and suspended in $2 \mathrm{ml}$ phosphate buffer. Mitochondrial fraction was frozen and thawed 3-5 times to release the enzymes (except complex IV which was extracted with $0.5 \%$ Tween 80 in phosphate buffer, v/v). The protein content was estimated in the supernatant according to the method of Lowry et al (1951). 


\section{Determination of the effect of G.lucidum on the activity of TCA cycle enzymes:-}

Isocitrate dehydrogenase (ICDH) activity was estimated according to the method of Fatania et al (1993) and the activity was expressed as micromoles of $\mathrm{NAD}^{+}$reduced $/ \mathrm{min} / \mathrm{mg}$ protein using extinction coefficient $6.3 \mathrm{mM}^{-1} \mathrm{~cm}^{-1}$. $\alpha$-Ketoglutarate dehydrogenase activity $(\alpha-\mathrm{KGDH})$ activity was estimated by the method of Reed and Mukherjee (1969). The activity was expressed as $\mu$ moles of $\mathrm{NAD}^{+}$(reduced $/ \mathrm{min} / \mathrm{mg}$ protein) using extinction coefficient of 6.3 $\mathrm{mM}^{-1} \mathrm{~cm}^{-1}$. Succinate dehydrogenase (SDH) activity was estimated by the method of Nulton-Persson and Szweda (2001) with slight modifications. The activity of SDH was calculated using the extinction coefficient of 2,6diclorophenol indophenol (DCIP) $\left(19.1 \mathrm{mM}^{-1} \mathrm{~cm}^{-1}\right)$ and expressed as $\mu$ moles of DCIP reduced $/ \mathrm{min} / \mathrm{mg}$ protein . Malate dehydrogenase (MDH) activity was estimated by the method of Mehler et al (1948) and the activity was expressed as $\mu$ moles of NADH oxidized $/ \mathrm{min} / \mathrm{mg}$ protein using the extinction coefficient of NADH $6.3 \mathrm{mM}^{-1} \mathrm{~cm}^{-1}$.

\section{Determination of the effect of G.lucidum on the activity of respiratory complexes:- Determination of Complex I}

Complex I activity was estimated by the method of Janssen et al (2007). Briefly $1 \mu \mathrm{mol} / \mathrm{l}$ antimycin A, $3 \mathrm{mg}$ BSA, $2 \mathrm{mmol} / 1 \mathrm{KCN}, 5 \mathrm{mmol} / 1 \mathrm{MgCl}_{2}, 65 \mu \mathrm{mol} / 1$ ubiquinone , $80 \mu \mathrm{mol} / \mathrm{l} \mathrm{DCIP}$ and mitochondrial protein (approximately $40 \mu \mathrm{g})$ were mixed with phosphate buffer $\left(25 \mathrm{mmol} \mathrm{p}^{\mathrm{H}} 7.2\right)$ in a net volume of $1 \mathrm{ml}$. Absorbance at $600 \mathrm{~nm}$ was monitored at $15 \mathrm{~s}$ interval for $2 \mathrm{~min}$ at room temperature after the addition of NADH $(0.2 \mathrm{mmol} / \mathrm{l})$. After $2 \mathrm{~min} 1$ $\mu \mathrm{mol} / \mathrm{l}$ rotenone was added and the absorbance was measured again for $2 \mathrm{~min}$ with an interval of $30 \mathrm{~s}$. The linear difference in absorbance was calculated before and after the addition of rotenone. The activity was expressed as $\mu$ moles of DCIP reduced $/ \mathrm{min} / \mathrm{mg}$ protein (extinction coefficient of DCIP is $19.1 \mathrm{mM}^{-1} \mathrm{~cm}^{-1}$ ).

\section{Determination of Complex III}

Decyl ubiquinol preparation: $1.3 \mathrm{mmol} / \mathrm{l}$ decylubiquinone was mixed with a few grains (approximately half volume) of sodium dithionate and vortexed vigorously. The transparent solution was centrifuged at $12,000 \mathrm{~g}$ for $10 \mathrm{~min}$. The supernatant containing decylubiquinol was used for the assay.

Complex III activity was estimated by the method of Krahenbuhl et al (1991). Mitochondrial protein (approximately $20 \mu \mathrm{g}$ ) was mixed with $100 \mu \mathrm{mol} / 1 \mathrm{EDTA}, 2 \mathrm{mg}$ BSA, $3 \mathrm{mmol} / 1$, sodium azide , $60 \mu \mathrm{mol} / 1$ ferricytochrome $-\mathrm{C}$, decylubiquinol and phosphate buffer $\left(50 \mathrm{mmol} / \mathrm{l}, \mathrm{p}^{\mathrm{H}} 8\right)$ in a final volume of $1 \mathrm{ml}$. The reaction was started by the addition of decylubiquinol and monitored for $2 \mathrm{~min}$ at 550nm and again after the addition of $1 \mu \mathrm{mol} / \mathrm{l}$ of antimycin A . The activity was calculated from the linear part of absorption time curve, which was not less than $30 \mathrm{~s}$. The extinction coefficient of ferricytochrome $\mathrm{C}\left(21 \mathrm{mM}^{-1} \mathrm{~cm}^{-1}\right)$ was used for the calculation . Activity of complex III was expressed as $\mu$ moles of ferricytochrome $-\mathrm{C}$ reduced $/ \mathrm{min} / \mathrm{mg}$ protein .

\section{Determination of Complex IV}

Preparation of ferrocytochrome $\mathrm{C}$ solution : $600 \mu \mathrm{mol} / \mathrm{l}$ ferricytochrome $-\mathrm{C}$ was stirred with a few grains of sodium dithionate in $30 \mathrm{mmol} / \mathrm{l}$ phosphate buffer $\left(\mathrm{p}^{\mathrm{H}} 7.4\right)$ for $10-20 \mathrm{~min}$ in the dark. The solution was centrifuged at $12,000 \mathrm{~g}$ for $10 \mathrm{~min}$. The transparent supernatant containing ferrocytochrome $\mathrm{C}$ was used for the complex IV assay.

Complex IV activity was determined by the method of Capaldi et al (1995) with slight modifications. Briefly $1 \mathrm{ml}$ of ferrocytochrome $\mathrm{C}$ solution was mixed with approximately $10 \mu \mathrm{g}$ of mitochondrial protein (extract in $0.5 \%$ Tween 80 in $30 \mathrm{mmol} / \mathrm{l}$ phosphate buffer, $\mathrm{p}^{\mathrm{H}} 7.4$ ) and phosphate buffer in net volume of $1.3 \mathrm{ml}$. The reaction was started by the addition of enzyme source and was monitored at $550 \mathrm{~nm}$ with an interval of $15 \mathrm{~s}$ for 4 min. The difference in absorbance was calculated from the linear part of the absorption - time curve complex IV activity was expressed as $\mu$ moles of ferrocytochrome $-\mathrm{C}$ oxidized $/ \mathrm{min} / \mathrm{mg}$ protein using the extinction coefficient.

\section{Determination of cardiac mitochondrial antioxidant status:-}

The mitochondrial supernatant was used for the estimation of antioxidant status. Reduced GSH level was estimated by the method of Moron et al. (1979) and the malondialdehyde (MDA) level by the method of Ohkawa et al. (1979) using 1,1,3,3,-tetra methoxy propane as the standard and expressed as $\mathrm{n}$ mol of MDA formed / $\mathrm{mg}$ protein.

\section{Statistical analysis:-}

All data were represented as mean \pm SD. The mean values were statistically analyzed using one - way analysis of variance (ANOVA) (using the Graph Pad Instat software package). The significant differences between the groups were further analyzed by Bonferroni's t-test .p values less than 0.05 were considered as significant. 


\section{Results:-}

The administration of G.lucidum extract (GLF) at its highest concentration $(500 \mathrm{mg} / \mathrm{kg})$ significantly increased the activities of TCA cycle enzymes (ICDH, $\alpha-\mathrm{KGDH}, \mathrm{SDH}, \mathrm{MDH}$ ) compared to the control group (Table 1). Standard (DL- $\alpha$-Lipoic Acid) also showed the similar results. But in the case of lower concentration $(250 \mathrm{mg} / \mathrm{kg})$ it was statistically non-significant from DOX control group. In the case of $\alpha-\mathrm{KGDH}$ and MDH irrespective of the concentration, G.lucidum extract showed significant activity compared to control. G.lucidum at its highest concentration only possessed statistically significant activity in the case of $\alpha-\mathrm{KGDH}$ and MDH enzyme assays.

Respiratory chain complexes I, III, IV in all the treated groups showed protective effect at their highest concentration $(500 \mathrm{mg} / \mathrm{kg})$ towards DOX control group(Table 2). GLF at lowest concentration $(250 \mathrm{mg} / \mathrm{kg})$ did not possess any significant protection to Complex III and IV activities .

Nevertheless, the GLF treated groups possessed remarkable protection against DOX control group in the case of lipid peroxidation (Figure 1). Similar results were observed in GSH also (Figure 2).

\section{Discussion:-}

Mitochondria have long been involved in an enormous number of cellular processes beyond its role in energy production. Cardiac cells rely upon mitochondria-generated ATP to sustain their normal homeostasis. Impairment of mitochondrial function due to anthracyclin antibiotics mainly DOX is widely studied. Due to an intricate sets of cellular and molecular mechanism of DOX induced cardiotoxicity , search to find out a compound which reduce the toxicity level at the same time maintains the antineoplastic activity of DOX is continued . Recently released FDA approved drug dexrazoxane, interferes with anti-cancer efficacy of DOX and there by increases the risk of secondary malignancies. Therefore, a compound which impart better and safer cardioprotection against DOX toxicity will clinch a great clinical attention. The results of the present study indicate that fruiting body extract of G.lucidum impart pronounced protection towards mitochondrial energy status of cardiomyocytes challenged with DOX.

DOX treatment causes distortion and destruction of respiratory complexes embedded in the inner mitochondrial membrane .Complex I, III and IV are the DOX sensitive sites in ETC. Along with nuclear DNA, DOX also forms adducts with mitochondrial DNA (mtDNA) and form complexes with cardiolipin, one of the most abundant phospholipid in the inner mitochondrial membrane (Minotti et al ; 2004). The redox cycling of DOX is catalysed by oxidoreducters present in ETC. DOX undergoes one electron reduction at Complex I , catalysed by NAD(P)H reductases to yield semiquinone radical and there by generating superoxide anion and other forms of reactive oxygen species. In addition to this, experimental studies show that an exogenous NADH dehydrogenase (cytosolic) is present which is specific to cardiomyocytes the key enzyme responsible for selective cardiotoxicity of anthracyclin antibiotics (Nohl et al ; 1998). GLF at its lowest concentration $(250 \mathrm{mg} / \mathrm{kg})$ is able to restore the electron flow of Complex I compared to DOX control . Earlier studies indicates that both the extracts of G. lucidum provide significant cardioprotection by validating serum cardiac marker enzymes such as CK and LDH (unpublished data).This hinges on the fact that Ganoderma extracts are capable to restore the alterations in oxidative phosphorylation consequent to DOX administration and thereby protecting the cardiomyocytes from DOX toxicity.

Besides, the activities of the respiratory chain complexes, Krebs cycle dehydrogenases was also declined in DOX treated control group. Earlier studies conducted by Ajith et al (2014) in our laboratory demonstrated the TCA cycle stimulating activity of G.lucidum (Sudheesh et al; 2010). DOX form complexes with metals like $\mathrm{Fe}^{3+}$ and $\mathrm{Cu}^{2+}$. As the result of bio sorption of G. lucidum, $\mathrm{Cu}^{2+}$ ions are removed from DOX complexes and $\mathrm{Ca}^{2+}$ ions are released into the mitochondrial membrane (Muraleedharan \& Venkobachar; 1994). $\mathrm{Ca}^{2+}$ can stimulate the TCA cycle dehydrogenases to increase the production of reduced substrate for respiratory chain complexes and further increase the rate of respiration. Our results is in agreement with this finding.Several dietary supplements, including the mitochondrial cofactor and antioxidant lipoic acid (LA), can increases the endogenous antioxidants as well as mitochondrial bioenergetics.

The deleterious action of DOX mainly affects the peroxidation of mitochondrial membrane lipids .Peroxidation of membrane phospholipids associated with a decrease in membrane fluidity which correlates with GSH content in the membrane there by reduced activity of TCA cycle enzymes. Our results reveal that pre-treatment with G.lucidum extracts significantly ameliorated DOX-induced cardiac oxidative damage by down regulating the generation of 
Thiobarbituric Acid Reacting Substances (TBARS) and augmenting GSH content .These results are in agreement with previous reports showing inhibitory activity of G. lucidum against membrane damage (Sudheesh et al ;2009).

\section{Conclusion:-}

In conclusion the results of the study indicate that aqueous ethanolic extract of G.lucidum is capable to protect the cardiomyocytes from DOX induced toxicity which hampered the TCA cycle and respiratory chain complexes in the mitochondria. Amelioration of toxicity by Ganoderma occurs in different ways: acting as a strong antioxidant, free radical scavenger, Topoisomerase II $\beta$ binding inhibitor etc. However the exact mechanism is still unknown and deserves further investigation.

Fig 1:- Effect of G. lucidum on Lipid Peroxidation

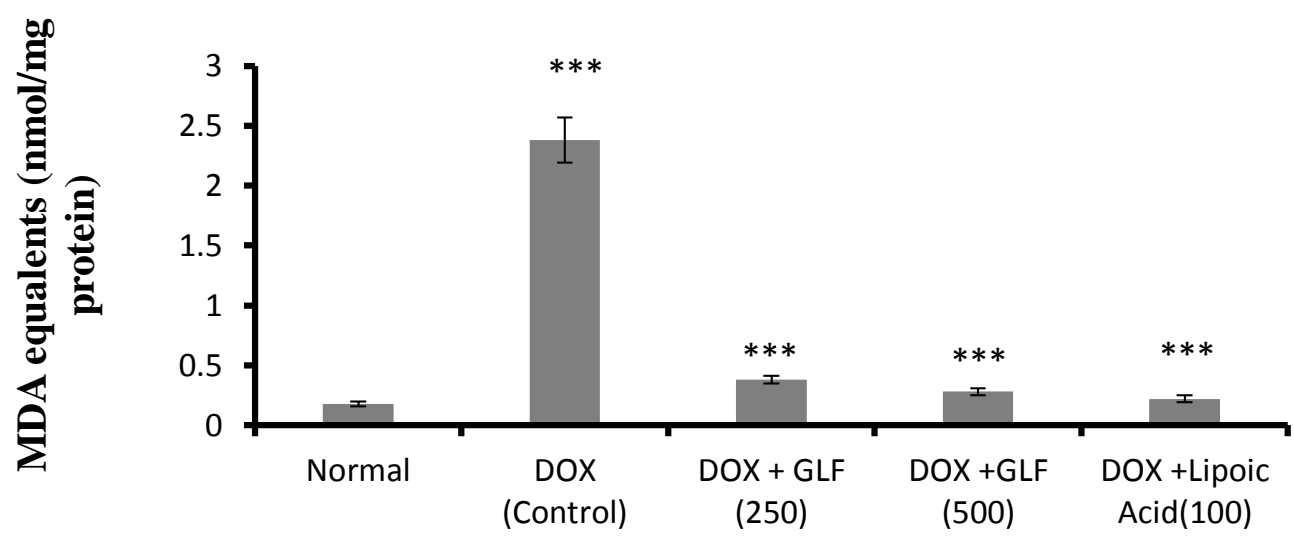

Treatments $(\mathrm{mg} / \mathrm{kg})$

Values are the mean $\pm \mathrm{S} . \mathrm{D} ; \mathrm{n}=6$ animals. ${ }^{* * *} \mathrm{P}<0.001$ significantly different from Doxorubicin control (Bonferroni test).DOX: Doxorubicin, GLF : G.lucidum extract

Fig 2:- Effect of G. lucidum on the levels of GSH activity

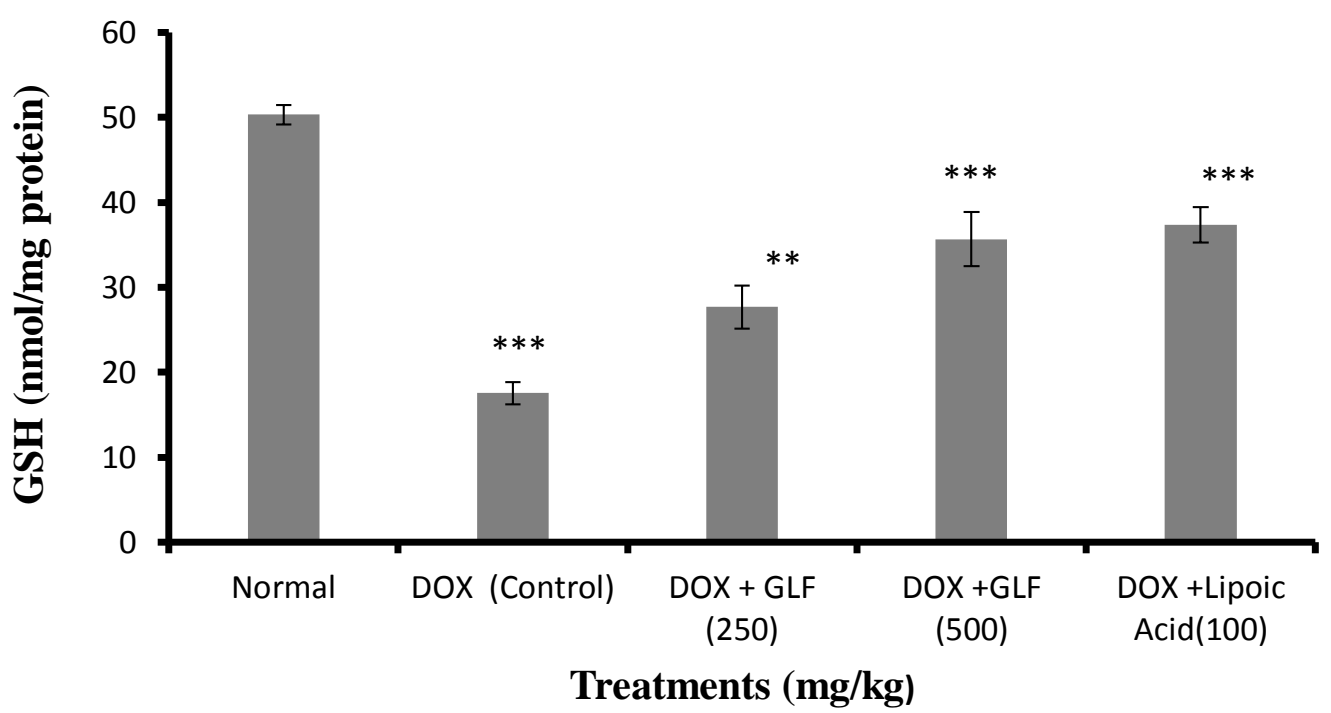

Values are the mean \pm S.D $; n=6$ animals. $* * * P<0.001$ significantly different from Doxorubicin control (Bonferroni test).DOX : Doxorubicin, GLF : G.lucidum extract 
Table 1:- Effect of aqueous ethanolic extract of G. lucidum on TCA cycle enzymes

\begin{tabular}{|c|c|c|c|c|c|}
\hline Groups & $\begin{array}{l}\text { reatments } \\
(\mathrm{mg} / \mathrm{kg})\end{array}$ & $\mathrm{ICDH}$ & $\alpha-\mathrm{KGDH}$ & SDH & MDH \\
\hline Normal & - & $1308.25 \pm 98.39$ & $621.24 \pm 35.78$ & $186.91 \pm 12.07$ & $3403.56 \pm 208.53$ \\
\hline $\begin{array}{l}\text { Doxorubicin } \\
\text { (Control) }\end{array}$ & $\begin{array}{l}\text { Cumulative } \\
\text { dose of } 18 \\
\mathrm{mg} / \mathrm{kg}(3 \\
\text { doses of } 6 \\
\mathrm{mg} / \mathrm{kg})\end{array}$ & $617.02 \pm 41.22^{* * *}$ & $200.4 \pm 15.0^{* * *}$ & $87.61 \pm 0.42^{* * *}$ & $337.69 \pm 11.34^{* * *}$ \\
\hline \multirow{2}{*}{$\begin{array}{l}\text { G.lucidum } \\
\text { (GLF) }\end{array}$} & 250 & $971.74 \pm 35.73^{*}$ & $392.58 \pm 11.31^{* * * *}$ & $123.08 \pm 3.15^{*}$ & $1944.85 \pm 106.28^{* * * *}$ \\
\hline & 500 & $1272.04 \pm 21.16$ & $503.87 \pm 17.11^{1 *}$ & $159.74 \pm 10.27$ & $2792.05 \pm 76.30^{*}$ \\
\hline $\begin{array}{l}\text { DL- } \alpha- \\
\text { Lipoic Acid }\end{array}$ & 100 & $1194.24 \pm 22.16^{* * * * *}$ & $588.06 \pm 24.78^{* * * *}$ & $159.74 \pm 10.27^{* * * *}$ & $2983.59 \pm 146.93^{* * * *}$ \\
\hline
\end{tabular}

Values are the mean \pm S.D; $(\mathrm{n}=6),{ }^{* * *} \mathrm{P}<0.001$ and $^{* * *} \mathrm{P}<0.01$ significantly different from Doxorubicin control Group (Bonferroni test).Units : Isocitrate dehydrogenase (ICDH)- $\mu$ moles of $\mathrm{NAD}^{+}$reduced $/ \mathrm{min} / \mathrm{mg}$ protein $; \alpha$ ketoglutarate dehydrogenase $(\alpha-\mathrm{KGDH})-\mu$ moles of $\mathrm{NAD}^{+}$reduced $/ \mathrm{min} / \mathrm{mg}$; succinate dehydrogenase (SDH) $\mu$ moles of DCIP reduced $/ \mathrm{min} / \mathrm{mg}$; malate dehydrogenase (MDH)- $\mu$ moles of $\mathrm{NADH}$ oxidized $/ \mathrm{min} / \mathrm{mg}$ protein.

Table 2:- Effect of aqueous ethanolic extract of G. lucidum on the respiratory complex

\begin{tabular}{|l|l|l|l|l|}
\hline \multicolumn{1}{|c|}{ Groups } & Treatments (mg/kg) & \multicolumn{1}{c|}{ Complex I } & Complex III & Complex IV \\
\hline Normal & - & $40.08 \pm 1.61$ & $12.02 \pm 1.08$ & $141.31 \pm 9.26$ \\
\hline $\begin{array}{l}\text { Doxorubicin } \\
\text { (Control) }\end{array}$ & $\begin{array}{l}\text { Cumulative dose of } 18 \\
\text { mg/kg(3 doses of } 6 \mathrm{mg} / \mathrm{kg})\end{array}$ & $9.42 \pm 1.93^{* * *}$ & $\begin{array}{l}3.77 \\
0.16^{* * *} \mathrm{~A}\end{array}$ & $24.06 \pm 0.73^{* * * *}$ \\
\hline $\begin{array}{l}\text { G.lucidum } \\
\text { (GLF) }\end{array}$ & 250 & $25.53 \pm 2.67^{* * *}$ & $6.51 \pm 0.38^{\mathrm{ns}}$ & $45.55 \pm 4.28^{\mathrm{ns}}$ \\
\hline DL- $\alpha$-Lipoic Acid & 500 & $37.12 \pm 2.33^{* * *}$ & $8.97 \pm 0.71^{* *}$ & $76.84 \pm 4.78^{* * *}$ \\
\hline
\end{tabular}

Values are the mean $\pm \mathrm{S} . \mathrm{D} ;(\mathrm{n}=6),{ }^{* * *} \mathrm{P}<0.001,{ }^{* *} \mathrm{P}<0.01$ significantly and $\mathrm{P}<0.05^{\mathrm{ns}}$ non - significantly different from Doxorubicin control Group (Bonferroni test).Units : Complex I - $\mu$ moles of DCIP reduced $/ \mathrm{min} / \mathrm{mg}$; Complex III - $\mu$ moles of ferricytochrome C reduced $/ \mathrm{min} / \mathrm{mg}$; Complex IV $-\mu$ moles of ferrocytochrome $\mathrm{C}$ oxidized $/ \mathrm{min} / \mathrm{mg}$.

\section{References:-}

1. Ajith, T. A., \& Jayakumar, T. G. (2014). Mitochondria-targeted agents: Future perspectives of mitochondrial pharmaceutics in cardiovascular diseases. World journal of cardiology, 6(10), 1091.

2. BB, H., Hellmann, K., Hermanl, E. H., \& Ferransi, V. J. (1998). Chemical, biological and clinical aspects of dexrazoxane and other bisdioxopiperazines. Current medicinal chemistry, 5(1), 1-28.

3. Capaldi, R. A., Marusich, M. F., \& Taanman, J. W. (1995). [9] Mammalian cytochrome-c oxidase: characterization of enzyme and immunological detection of subunits in tissue extracts and whole cells. Methods in enzymology, 260, 117-132.

4. Cocco, T., Cutecchia, G., Montedoro, G., \& Lorusso, M. (2002). The antihypertensive drug carvedilol inhibits the activity of mitochondrial NADH-ubiquinone oxidoreductase. Journal of bioenergetics and biomembranes, 34(4), 251-258.

5. Fatania, H., Al-Nassar, K. E., \& Sidhan, V. (1993). Purification and partial characterisation of NADP+-linked isocitrate dehydrogenase from rat liver cytosol. FEBS letters, 320(1), 57-60.

6. Goormaghtigh, E., Huart, P., Praet, M., Brasseur, R., \& Ruysschaert, J. M. (1990). Structure of the adriamycincardiolipin complex: role in mitochondrial toxicity. Biophysical chemistry, 35(2-3), 247-257.

7. Janssen, A. J., Trijbels, F. J., Sengers, R. C., Smeitink, J. A., Van den Heuvel, L. P., Wintjes, L. T., \& Rodenburg, R. J. (2007). Spectrophotometric assay for complex I of the respiratory chain in tissue samples and cultured fibroblasts. Clinical chemistry, 53(4), 729-734.

8. Khiati, S., Dalla Rosa, I., Sourbier, C., Ma, X., Rao, V. A., Neckers, L. M., \& Pommier, Y. (2014). Mitochondrial topoisomerase I (Top1mt) is a novel limiting factor of doxorubicin cardiotoxicity. Clinical Cancer Research, 20(18), 4873-4881. 
9. Krahenbuhl, S., Chang, M., Brass, E. P., \& Hoppel, C. L. (1991). Decreased activities of ubiquinol: ferricytochrome c oxidoreductase (complex III) and ferrocytochrome c: oxygen oxidoreductase (complex IV) in liver mitochondria from rats with hydroxycobalamin [c-lactam]-induced methylmalonic aciduria. Journal of Biological Chemistry, 266(31), 20998-21003.

10. Lakshmi, B., Ajith, T. A., Sheena, N., Gunapalan, N., \& Janardhanan, K. K. (2003). Antiperoxidative, antiinflammatory, and antimutagenic activities of ethanol extract of the mycelium of Ganoderma lucidum occurring in South India. Teratogenesis, carcinogenesis, and mutagenesis, 23(S1), 85-97.

11. Lowry, O. H., Rosebrough, N. J., Farr, A. L., \& Randall, R. J. (1951). Protein measurement with the Folin phenol reagent. Journal of biological chemistry, 193(1), 265-275.

12. Mahesh, B. U., Shrivastava, S., Kuncha, M., Sahu, B. D., Swamy, C. V., Pragada, R. R., \& Sistla, R. (2013). Ethanolic extract of Boswellia ovalifoliolata bark and leaf attenuates doxorubicin-induced cardiotoxicity in mice. Environmental toxicology and pharmacology, 36(3), 840-849.

13. Mehler AH, Kornberg A, Grisolia S, Ochoa S (1948). The enzymatic mechanism of oxidation-reductions between malate or isocitrate and pyruvate. Journal of Biological Chemistry, 174, 961.

14. Minotti, G., Menna, P., Salvatorelli, E., Cairo, G., \& Gianni, L. (2004). Anthracyclines: molecular advances and pharmacologic developments in antitumor activity and cardiotoxicity. Pharmacological reviews, 56(2), 185229.

15. Moron, M. S., Depierre, J. W., \& Mannervik, B. (1979). Levels of glutathione, glutathione reductase and glutathione S-transferase activities in rat lung and liver. Biochimica et Biophysica Acta (BBA)-General Subjects, 582(1), 67-78.

16. Muraleedharan, T. R., \& Venkobachar, L. I. (1994). Further insight into the mechanism of biosorption of heavy metals by Ganoderma lucidum. Environmental technology, 15(11), 1015-1027.

17. Nohl, H., Gille, L., \& Staniek, K. (1998). The exogenous NADH dehydrogenase of heart mitochondria is the key enzyme responsible for selective cardiotoxicity of anthracyclines. Zeitschrift für Naturforschung C, 53(3-4), 279-285.

18. Nulton-Persson, A. C., \& Szweda, L. I. (2001). Modulation of mitochondrial function by hydrogen peroxide. Journal of Biological Chemistry, 276(26), 23357-23361.

19. Ohkawa, H., Ohishi, N., \& Yagi, K. (1979). Assay for lipid peroxides in animal tissues by thiobarbituric acid reaction. Analytical biochemistry, 95(2), 351-358.

20. Reed, L. J., \& Mukherjee, B. B. (1969). [12] $\alpha$-ketoglutarate dehydrogenase complex from Escherichia coli. Methods in enzymology, 13, 55-61.

21. Sliva, D. (2004). Cellular and physiological effects of Ganoderma lucidum (Reishi). Mini reviews in medicinal chemistry, 4(8), 873-879.

22. Smina, T. P., De, S., Devasagayam, T. P. A., Adhikari, S., \& Janardhanan, K. K. (2011). Ganoderma lucidum total triterpenes prevent radiation-induced DNA damage and apoptosis in splenic lymphocytes in vitro. Mutation Research/Genetic Toxicology and Environmental Mutagenesis, 726(2), 188-194.

23. Sudheesh, N. P., Ajith, T. A., \& Janardhanan, K. K. (2009). Ganoderma lucidum (Fr.) P. Karst enhances activities of heart mitochondrial enzymes and respiratory chain complexes in the aged rat. Biogerontology, 10(5), 627-636.

24. Sudheesh, N. P., Ajith, T. A., Janardhanan, K. K., \& Krishnan, C. V. (2010). Effect of POLY-MVA, a palladium $\alpha$-lipoic acid complex formulation against declined mitochondrial antioxidant status in the myocardium of aged rats. Food and Chemical Toxicology, 48(7), 1858-1862.

25. Tsutsui, H., Kinugawa, S., \& Matsushima, S. (2008). Mitochondrial oxidative stress and dysfunction in myocardial remodelling. Cardiovascular research, 81(3), 449-456.

26. Wasser, S. P. (2010). Medicinal mushroom science: history, current status, future trends, and unsolved problems. International Journal of Medicinal Mushrooms, 12(1). 